\title{
Competitiveness of Chinese Industries - A Comparison with the EU
}

\author{
Jianhong Zhang \\ Nyenrode Business University, the Netherlands, and YNUFE, China \\ Europe China institute, Nyenrode Business Universiteit \\ Straatweg 25, 3621 BG Breukelen, Netherlands \\ Tel: 31-346-291-764Ｅ-mail:j.zhang@nyenrode.nl \\ Haico Ebbers \\ Nyenrode Business University, the Netherlands, and CEIBS, China. \\ Europe China institute, Nyenrode Business Universiteit \\ Straatweg 25, 3621 BG Breukelen, Netherlands \\ Tel: 31-346-291-273Ｅ-mail: h.ebbers@nyenrode.nl \\ René Mulder \\ Everett, the Netherlands \\ Wiersedreef 5-7, 3433 ZX Nieuwegein, Netherlands
}

Received: November 10, 2011

Accepted: December 12, $2011 \quad$ Published: March 1, 2012

doi: $10.5539 /$ res.v4n1p203

URL: http://dx.doi.org/10.5539/res.v4n1p203

\begin{abstract}
This study develops a two-dimension and multi-variable approach to investigate the competitiveness and dynamics of Chinese industries (products groups). The result reveals the orderly transformation of competitiveness across 97 Chinese industries. In order to determine the position of China's industries in the world market, we also investigate the competitiveness of the EU-15's industries using the same approach. The orderly transformation of competitiveness of Chinese industries is found to follow the current competitiveness pattern of the EU-15, which is in line with the orderly transfer of economic activities between developing and developed countries as predicted by theoretical models.
\end{abstract}

Keywords: Competitiveness, Export performance, Export potential, Reveal of comparative advantage, Chinese industries

\section{Introduction}

Globalization creates an integrated market and a system of global production. No country can escape from the influence of globalization, and no country intends to exclude itself from the process of globalization. Even countries that once took on an inward orientated strategy are connecting their economies with the world network by liberalizing the movement of good, services, and capital across borders. This trend greatly changes not only the pace of development in these countries but also their worldwide competition map and the position of countries on the map. These changes have generated widespread interest in national competitiveness among scholars and policy makers. In recent years, emerging economies and their globalization have attracted substantial attention from the western world. The challenges and opportunities of emerging economies is a popular debating point, and China is the most talked-about country in this debate.

In the last decade, a number of studies have discussed the impact of the rise of China on the rest of the world. These studies either investigated the aggregative impact on broad regions of the world,or specifically analyzed the impact on China's neighbors in Asia and other developing countries in America and Africa (e.g., Lam, 1997; Yang, 2003; Lall and Albaladejo, 2004; Lall and Weiss, 2005; Jenkins, Peters and Moreira, 2008). A couple of 
studies have discussed the effect on developed countries, such as the US (Britton and Mark, 2006) and the Netherlands (Suyker and Groot, 2006). These studies shed some light on the impact of China on the rest of the world. However, most of these studies investigated the impact of China on price, productivity and employment at the macro level of countries or regions. Attention has rarely been directed, to date, to the analysis of the competitiveness of China's products with a broad range and its implications for the opportunities and challenges created by China.

Many observers have expressed concern over the increasing centralization of the world's manufacturing production in China, especially with the EU or US losing competitiveness.. In response to this concern, several studies investigated China's competitiveness at a macro level, revealing its state, changes and drivers (Adams, 2006; EL-Namaki, 2002; Zhao and Zhang, 2007). A couple of studies also investigated the competitiveness of one particular industry (Chen et al., 2000; Hu et al., 2004; Sha et al., 2008). A few studies investigated the competitiveness of Chinese firms in international market (Guan and Ma, 2003). These studies improved our understanding of China's competitiveness, but, in our knowledge, few studies paid attention to cross-industry analysis. In order to understand the impact of the rise of China on the rest of the world, we need to know which industries are more competitive and how their competitiveness changes over the time. Although a couple of studies use the Balassa index to identify China's industrial comparative advantage (Hinloopen and Marrewijk, 2004), a single indicator does not show a complete picture of competitiveness.

To fill these gaps in the literature, this paper aims to investigate competitiveness of China's industries by using a two-dimension and multi-variable approach, and to discuss the potential impact of competitiveness dynamics of China's products on more advanced economies, using EU as a case study.

\section{Literature Review}

Although competitiveness is a widely used concept, the measurement of competitiveness calls for further study because the concept of competitiveness lacks a universally accepted definition and there is little consensus on the appropriate empirical measures. Competitiveness has been applied to different unit levels and measured by different indices. In the literature, competitiveness has been studied at the country level, regional level, industry level, firm level and even the group level. At different levels, studies focus on different characteristics of the unit investigated.

The most quoted definition of a nation's competitiveness is given by Laura D'Andrea Tyson: "competitiveness is the ability to produce goods and services that meet the test of international competition while our citizens enjoy a standard of living that is both rising and sustainable" (Tyson 1992). Macro-concepts and indices focus on productivity (Dollar and Wolff 1993, Hatsopoulos et al. 1988), real exchange rate (Corden 1994, Marsh 1996), institutions, policies and factors that determine the level of productivity of a country (WEF/IMD annual since 1995) (Note 1). These measures can provide a suitable context for comparing the general environments of countries, although the measurements of national competitiveness suffer from problems of validity and a lack of suitable and meaningful data (Krugman 1994).

At the industry and firm level, competitiveness is considered the ability and performance of a firm, or a sector to sell and supply goods and/or services in a given market. The micro- and meso-economic concepts and indices of competitiveness have a more solid theoretical base; they focus on the essential characteristics of producers in competition for market share and profits or the ability to export (Siggel, 2006). In literature, the ability has been measured by market share (Mandeng, 1991; Makhija et al., 1997; Kaminski, 2000), balance of trade (DeCourcy, 2007), reveal of comparative advantage (Balassa, 1966), intra-industry trade (Havrylyshyn and Kunzel, 1997; Makhija et al., 1997), Terms of trade (Daniel III, 2000), unit cost (Siggel, 2001), Productivity (Markusen, 1992; Oral et al., 1999), increase of market share (Mandeng, 1991), price ratios (Durand and Giorno, 1987), or multidimensional indicators (Makhija et al., 1997, Buckley et al., 1992; Oral, 1993).

These measurements reveal different attributes of competitiveness. Some approach it from a causal perspective, investigating the sources of the competitiveness; others from resultant perspective, uncovering the outcome of the competitiveness. Some focus on the current situation of competitiveness; others focus on the potential position of competitiveness. There are more attributes distinguished in the literature, which can be found in the survey of Buckley et al. (1988) and Siggel (2006). Table 1 presents the ones that are relevant to the industrial level concept. Taking a close look at these measurements, one can easily see that a single measure does not capture all the elements of competitiveness. Therefore multi-dimensional indicators are becoming popular in the business economics literature, especially in studies that focus at the firm level (Oral 1993, Buckley et al. 1992) and country level (Porter 1990). At the industry level, studies using the multi-dimensional approach are very limited. Makhija et al. (1997) proposed a two-pronged measure of industry globalization, a concept that is 
closely linked to competitiveness. Two variables, export share and intra-industry trade, are included in the measurement. This study follows the two-pronged idea, developing a two-dimension and multi-variable framework measuring competitiveness at the industry level. This framework is then applied to a wide range of industries in China, and EU by using data from 2000 to 2005.

The study adds the value to the literature in following ways. First, by using a two-dimension and multi-variable approach, this study provides a more comprehensive measurement for competitiveness than previous studies. Second, by using the most recent year's data, this study sheds light on the current situation, taking into account recent major political and economical reforms and transitions, such as China's entry into WTO in 2001.Third, the study is based on more disaggregated level data, i.e. the 6 digit level of HS classification, which captures the structure effect and measures more effectively.

\section{Examining Competitiveness Indicators}

When an indicator is assumed to assess competitiveness, it is important to determine if it represents the "source" or the "outcome" of competitiveness. For example, low cost, price and high productivity are causes of a producer's strong competitiveness, while trade performance, -- including trade balance, market share, and reveal of comparative advantage index, represent the results of the international competitiveness. This paper focuses on ex post concepts, assessing the competitiveness from the resultant perspective. The advantage of doing so is that we can use trade data to measure international competitiveness directly. Trade data is available for almost all countries in great detail, and worldwide standard statistics methods make the data comparable across the countries and industries. This attribute endows the research framework developed in this study with high practicality.

To investigate competitiveness dynamics, we apply a two-dimension approach. One dimension reveals the competitive performance, while the other reveals the competitive potential. For either dimension of competitiveness, a single variable cannot capture all the elements of the relevant concepts, so we apply a multi-variable approach to form an indicator of each dimension.

\subsection{Indicators for competitive performance}

\subsubsection{Reveal of comparative advantage (RCA)}

The RCA index is a wildly used measure for comparative advantage. A general interpretation of the principle of comparative advantage is that a producer has comparative advantage if the producer can produce a good at a lower opportunity cost than that of a competitor. The sources of the comparative advantage can be the abundance (cheapness) of either primary or intermediate inputs (extended Heckscher-Ohlin model), or the use of different technology (Ricardo), or the production at larger scale (Krugman), or any combination of the former sources, such as in the product cycle model (Vernon) (Siggel 2006: 139). Competitive advantage, on the other hand, comes not only from these factors, but also from price distortions. Siggel (2001) argued that competitiveness is a combination of comparative advantage and price distortion-based factors such as policy. He maintains that the RCA index measures competitiveness rather than comparative advantage (e.g. Siggel, 2006). The original RCA index, formulated by Balassa (1965), identifies whether a country has a "revealed" comparative advantage by using trade data, but it does not determine the underlying sources of comparative advantage. So Following the argument of Siggel, RCA index is an ex post measure of competitiveness. We include RCA index into the multi-variable indicator of competitive performance.

Since first suggested by Balassa (1965), the definition of RCA has been revised and modified by many researchers. A problem with Balassa's RCA index is its asymmetry. The index ranges from zero to one if a country is not specialized in a given sector, but the index ranges from one to infinity, if a country is specialized. Vollrath (1991) suggests taking the logarithm of the RCA as a solution to this problem. However, this still leaves the problem of zero exports, in which case the RCA would not be defined. Laursen (1998) suggests making the index symmetric by using the following adjustment: RSCA $=(\mathrm{RCA}-1) /(\mathrm{RCA}+1)$. This is called the Revealed Symmetric Comparative Advantage (RSCA). A positive value indicates comparative advantage, and a negative value of RSCA indicates comparative disadvantage. This paper adopts the RSCA.

\subsubsection{Export share}

Market share is a commonly used measure of a firm's performance. where a large or increasing market share is the result of successful competition. This study uses China's exports share out of total world exports for a given industry as one measure of competitiveness. In the literature, studies either use RCA or exports share, since the two indexes are quite similar. The main difference is that the RCA is the exports share divided by a country's share in total world exports. RCA more focuses on comparison across industries in a country. The export share, 
on the other hand, shows the absolute capacity of the competition in the world market; it can be used in cross-countries comparison. This study includes these two variables in the indicator in order to capture different aspects of competitiveness.

\subsubsection{Balance of trade}

Since competitiveness is considered the ability of producers to sell products in the global market, balance of trade -- the difference between the value of exports and imports-- can be used to measure the ability to export. Although some economists argue that using balance of trade as indicator of competitiveness is misleading (Markusen 1992), many studies have employed this index to measure the competitiveness (Buckley 1988; DeCourcy, 2007). Our standpoint is, using the balance of trade as a single indicator of competitiveness is not without its limitations, but using it as a part of the measure is recommendable. The reason is as following. First, as this paper focuses on ex post concepts, trade performance is the center of the discussion, and the balance of trade is an important part of trade performance. Second, the balance of trade takes both exports and imports into account, which is necessary especially when domestic market is large and should be taken as a part of global market. When exports and imports both increase, it is only a sign of descreasing competitiveness if import increases more relative to exports (Rugman and D'cruz, 1989). In addition, balance of trade to a certain extent reflects the effect of price distortion-based factors from the imports side. For example, when a country protects its industry by setting import barriers, balance of trade may be improved while its exports remain the same.

The features of balance of trade noted above suggest that it is an important complementary of the RCA index and export share. These three variables are closely linked to each other, but they represent different aspects of competitiveness. We combine the three variables into one indicator to gauge competitiveness performance.

\subsection{Indicators for competitive potential}

\subsubsection{Unit export price}

Price is considered one important source of trade success. In an econometric model Fagerberg (1988) suggested that price is one determinant of international competitiveness. Buckley (1988) classified the relative unit export price as a measure of potential competitiveness. In practice, export price closely corresponds to the sources of competitiveness, such as those affecting comparative advantage, e.g. factor productivity, factor abundance and transportation cost, and those related to price distortion-based factor, e.g. exchange rate and trade policy. This attribute gives unit export price a predictive value for competitiveness, and therefore can be one indicator of competitive potential.

\subsubsection{Relative export growth}

Growth rate is commonly used as a predictive variable. We include the export growth as a part of our potential indicator. However, using absolute export growth rate to measure the potential competitiveness may be misleading. For instance, a demand shock in the world market may influence all countries' export paces in the related industry, while the competitiveness may remain the same. To solve this problem, this study uses the relative export growth rate, which is the value of a county's exports growth rate in a given industry relative to the world trade growth rate in the same industry. The basic idea is a higher growth rate related to the world suggests a higher potential of the country in the given industry. The relative export growth also helps identify dynamic and static industries.

\subsubsection{Mandeng's K}

The starting point of Mandeng's $\mathrm{K}$ is that overall benefits of competition are largely determined by dynamic changes in market patterns (Mandeng, 1991). The RCA is static, but it is possible to make it dynamic by focusing on comparisons over the time and items of the rates and changes. Using a dynamic measure is important in prediction. If a country gained a big market share in a particular product, it enjoys high RCA. But if total trade of this product in the world market has declined in recent years, which means the market of this product is shrinking, it is not a good sign for overall future competitiveness. The Mandeng handled this problem by distinguishing between commodity groups that have increasing or decreasing share in the world market (Mandeng 1991). If a commodity group has a high RCA and demand of this group is increasing, then this group has high competitiveness potential; if a commodity group has a high RCA but demand of this group is decreasing, then exports of this group may decline in the future. In other words, a high RCA in a growing market is regarded as a positive contribution to the potential competitiveness, while a high RCA in a declining market is regarded as low potential. This variable, similar to relative market share growth, generally has a predictive capacity.

Competitiveness potential can only be measured indirectly and is determined by several different components (Momoya, 1998). Relative unit export price, relative export growth and Mandeng's K reflect different aspects of 
the competitiveness potential. They are not closely related to each other, but they are equally important in assessing an industries' competitiveness potential. For example, if an industry of a country has a cost advantage, indicated by a low relative unit export price, it may have a high potential. However, if the markets of most products in this industry are declining all over the world, indicated by low Mandeng's K, one cannot expect that the industry of this country will grow in future. Therefore it is important to have a comprehensive indicator that combines different elements of competitiveness potential.

Beside the variables discussed above, terms of trade have also been used in the literature In practice, a country's terms of trade is defined as the ratio of an index of the world prices of its exports to an index of the world prices of its imports. It often used as a proxy for the relative social welfare of a country. When a country's terms of trade improve, its exports effectively buy more imports. The country can thus import more or export less while maintaining a balanced trade. Clearly, an increase in a country's TOT increases its welfare. However, using terms of trade to measure an industry's competitiveness lacks theoretical base. On the one hand, an increase in TOT may improve the trade balance, hence competitiveness (Daniel 2000). On the other hand, the price of exports and imports of a country can be heavily influenced by the value of its currency. If the increase in TOT is caused by an increase in exchange rate, competitiveness in the manufacturing sector may be squeezed. Therefore it is not a clear-cut measure of competitiveness, and it is not included in the indicator developed in this study.

\section{Data and Methodology}

The trade data used in this study is from the database of United Nations (Comtrade) and the OECD OECD.STAT). The study period is 2000 to 2005. For commodity classification, we chose to use the Harmonized System nomenclature instead of SICT. The main reason is that the Harmonized System recognizes over 5000 product groups on the most disaggregated level, compared to 2970 groups in the SITC classification. This additional resolution allows for a more in-depth analysis of trade patterns and trend. In addition, China uses Harmonized System nomenclature in most of publications, and China's trade statistics matches the world's very well in the Harmonized System (Note 2).

\section{1 measures of the variables}

1) Revealed Symmetric Comparative Advantage (RSCA)

In line with the discussion above, we calculate the RSCA as following:

$$
\begin{aligned}
& R S C A_{i j}=\frac{R C A_{i j}-1}{R C A_{i j}+1} \\
& R C A_{i j}=\frac{X_{i j} / X_{i w}}{X_{j} / X_{w}}
\end{aligned}
$$

where $\mathrm{X}_{\mathrm{ij}}$ is the export value of country $\mathrm{j}$ in $\mathrm{i}$ product group/industry; $\mathrm{X}_{\mathrm{iw}}$ world export in $\mathrm{i}$ product group/industry; $\mathrm{X}_{\mathrm{j}}$ is total exports in country $\mathrm{j} ; \mathrm{X}_{\mathrm{w}}$ is total export in the world.

2) Export share (ES)

Export share is calculated by dividing the export value of China by the total global trade value of the same commodity.

$$
E S_{i j}=X_{i j} / X_{i w}
$$

3) Balance of Trade (BT)

Balance of Trade is the difference between exports and imports. Considering the effect of the size of the sector, the study uses trade size (exports plus imports) to weigh the trade balance.

$$
B T_{i j}=\frac{X_{i j}-M_{i j}}{X_{i j}+M_{i j}}
$$

Where $\mathrm{M}$ represents import value.

4) Relative unit export price (RUV) 
Relative unit export price is the ratio of unit value of the world exports to the unit value of the county concerned in a specific industry.

$$
\begin{gathered}
R U V_{i j}=U V_{i w} / U V_{i j} \\
U V_{i j}=X_{i j} / Q_{i j} \quad U V_{i w}=X_{i w} / Q_{i w}
\end{gathered}
$$

Where $U V_{i w}$ is unit value of commodity i of the world exports; $U V_{i j}$ is unit value of commodity $i$ of country $j$. $Q_{i j}$ is quantity of commodity $i$ of country $j$; $Q_{i w}$ is quantity of commodity $i$ of the world (Note 3 ). If RUV is above 1 , that means unit export value of country $\mathrm{j}$ is lower than the world average, which implies that the competitiveness of country $\mathrm{j}$ is high.

To calculate the unit price, the most disaggregated data is preferred. Therefore we first calculate the unit price at to the six-digit level, than aggregated it into the two- digit level by using formula 4.7.

$$
r u v_{i j}=\frac{\sum_{\mathrm{t}} u v_{t w} \cdot v_{t w}}{\sum_{t} v_{t w}} / \frac{\sum_{t} u v_{t j} \cdot v_{t w}}{\sum_{t} v_{t w}} \mathrm{t} \in \mathrm{i}
$$

Where $t$ denotes the numbers of six-digit commodities that belong to $\mathrm{i}$ commodity group. The $\mathrm{i}$ is in two-digit division.

5) Relative export growth

Relative export growth is the growth of exports of one country compared to the growth of world trade in a given product group/industry.

$$
\operatorname{reg}_{i j}=\frac{X_{i j, 2005} / X_{i j, 2000}}{X_{i w, 2005} / X_{i w, 2000}}
$$

\section{6) Mandeng's K}

Mandeng's K indicates potential competitiveness based on the current international trade position. It is a ratio of two balassa indices: the balassa index in the 'growing' subgroup divided by the balassa index in the 'declining' subgroup. The first step is to distinguish the growing group from declining group by using the world trade data at six-digit level. Given the upward trend of the world trade, we use the median of growth rates of all trade subgroups as a benchmark. The growth rate is calculated based on trade data in period of 2000 to 2005 . A subgroup is considered as a growing/declining group if the trade growth rate is higher/lower than the median. The second step is to aggregate the growing and the declining commodities respectively from six-digit to two-digit level. Then calculate the RSCA for both growing group and declining group. The formula for Mandeng's $\mathrm{K}$ is:

$$
K_{i j}=\frac{R S C A_{i j, i n c}}{R S C A_{i j, d e c}} ;
$$

\subsection{Competitiveness matrix}

The evaluation of competitiveness is based on $2 \times 2$ competitiveness matrix. Horizontal axis shows the competitiveness performance and vertical axis the competitiveness potential. Each quadrant of the matrix 
exemplifies an industry-specific combination of competitiveness position: New Waves, Stars, Falling Stars and Retreats. The global competitiveness path runs as the arrows indicate in the Figure 1. Those in the New Waves quadrant do not yet perform strongly but reveal strong potential; they can be expected to move to the quadrant of Stars. Those in the Stars quadrant show both strong potential and current performance; they may fall down to the Falling Stars quadrant when the life cycle of the product enters the later stage, and it faces the competition from emerging economy. Those in Falling Stars quadrant show strong current performance and low potential; they may move to the quadrant of Retreats due to the low growth rate. Those in the Retreats quadrant show poor performance and low potential; they may move to the quadrant of New Waves due to the environment change (world market) and innovation.

\subsection{Combination of Proxies}

As stated above, three variables -- revealed symmetric comparative advantage, export share, and balance of trade -- influence the current competitiveness performance. The other three variables -- relative unit export price, the relative export growth and Mandeng's K -- show the competitiveness potential. To obtain a numerical representation for either current competitiveness or competitiveness potential, three variables have to be combined. We calculate a average of the variables after standardizing the data using formula $4.10 \ldots$

$$
y=\frac{(x-\bar{x})}{\sigma_{x}}
$$

\section{Results}

Following the methods explained above, indicators of competitiveness of Chinese industries are calculated and plotted in figure 2. The data were aggregated into two-digit level, and 97 industries are investigated. According to the figure 2, those in the lower-left quadrant (Retreads) are mostly from three industries. 1) Primary sector, such as meat and edible fruit, foodstuff and milling products. 2) chemical industry, especially those of basic chemicals (e.g. fertilizers and plastics) and consumer chemical products. 3) metal industry, especially those products related to copper, nickel, zinc and tin etc.

Those in the upper left quadrant (New Waves) as also from above mentioned three industries, but from different sub industries with different product characteristics. Specifically, products in primary industry are live products, cocoa, and tobacco, ores and slag etc; products from chemical industry are pharmaceutical products, albuminoids modified starches, enzymes; products from metal industry are iron and steel. Besides, vehicles other than railway and tramway are also in this quadrant.

The products in the upper right quadrant (Stars) are those of aluminum, lead and related metal products, wood, stone and glass, some textile products, machinery and electronics, transportation, etc.

The products in the lower right quadrant (Falling Stars) are those of primary products (e.g. fish, vegetable, salt etc.), most of textiles, footwear and headgear, and most of miscellaneous. The details can be found in Table 2 .

The indicators of competitiveness position of EU-15's industries are calculated and plotted in figure 3 by using the same method. Comparison of competitiveness situation of China and the EU provides an interesting observation. The two economies have a different pattern of the position of the various industries across the four quadrants, only 11 out of 97 industries show the similar position in the two figures. However, having a close look, we find that there is a clear link between these two patterns. Specifically, most industries located in the New Waves quadrant for China are in the Stars and Falling Stars quadrant for the EU; and most industries in the Stars quadrant for China are in the Falling Stars and Retreats quadrant for the EU; and most industries in the Falling Stars quadrant for China are in the Retreats quadrant for the EU. If the links are represented by an arrows, the clear global competitiveness path appears between China and the EU (Figure 4). This orderly transformation in China and the EU in terms of competitiveness is quite similar to the orderly sequencing of economic activities formulated in some economics models, such as the product cycle theory (Vernon 1966) and the fly geese paradigm (Kojima, 2000).

\section{Discussion and conclusion}

This study develops a two-dimension and multi-variable approach to investigating the competitiveness of industries (products groups). The approach developed herein uses a two-dimension framework to analyze industry dynamics. One dimension indicates competitiveness performance, which is a combination of three variables: RSCA, export share, and balance of trade. The second dimension indicates competitiveness potential, which takes into account three variables: relative unit export price, relative export growth and Mandeng's K. The 
result demonstrated in Figure 2 reveals the orderly transformation of competitiveness across 97 Chinese industries. It is clear that Chinese competitiveness is shifting from low-value added products to high-value-added products, which is in line with the commonly accepted growth path.

In order to compare the competitiveness dynamics of China and western countries, we choose the EU as a case study. An interesting finding of this study is that the orderly transformation of competitiveness of most Chinese industries follows the current competitiveness pattern of EU-15. Specifically, if an industry is in the New Waves for China, it is in the Stars quadrant for the EU; an industry is in the Stars quadrant for China, it is in the Falling Stars quadrant for the EU, an industry is in the Falling Stars quadrant for China, is in the Retreats quadrant for the EU. This sequencing implies the orderly transfer of industrial activities between EU and China.

In the literature, three type of orderly sequencing of economic activities have been formulated. 1) The first type concerns the product-cycle sequencing of a particular product (or a product group), the process moving from import-substituting production to production for export. 2) The second type describes industry-cycle sequencing based on shifting comparative advantages; a country shifts production activities from lower value-added, more labor-intensive and less capital-intensive industries to the higher value-added, less labor-intensive and more capital-intensive industries. 3) The third type describes inter-economy sequencing entailing orderly transfer of industrial activities among economies (Ozawa, 2005).

This study observes these sequences from the perspective of competitiveness, demonstrating inherent relationships between competitiveness and economic activities. The finding of this study mainly concern the last two types of orderly sequencing activities. The competitiveness path indicated in Figures 1 and 2 is in line with the industry-cycle sequencing, showing the trends of competitiveness of Chinese industry. The link between Chinese pattern and EU pattern demonstrated in Figure 4 is in line with the inter-economy sequencing, demonstrating the orderly transformation of competitiveness between the EU and Chinese industries. These two types of sequences in our competitiveness context are closely linked to each other. On the one hand, western countries' internal transformation in terms of competitiveness drives multinationals to move their production to China, enhancing the competitiveness of China in the relevant industry. That is, if an internal restructuring in the EU results in an industry moving from Stars to Falling Stars, the Chinese counterpart may gain a chance to grow and move from New Waves to Stars. On the other hand, if an internal restructuring in China results in an industry moving from category New Waves to Stars, the EU countpart which is in the Stars may face the challenge and move downward to Falling Stars. The examples can be found in the industries like glass, fur, skins and some sub-industries in textile. However, we should exert cautious in explaining the causalities. The causalities should not explain exclusively between the relationship between China and EU. The fall of an industry's competitiveness in EU should not attribute only to the rise of China, other emerging economies also count. According to the orderly transformation of competitiveness maintained in this study, even if China did not emerge, other economies will rise and place the same challenge.

This study offers a useful framework for identifying competitiveness dynamics of industries within and between economies. It serves as an analysis tool in industry restructuring, strategic management and international business, helping government and firm decision-makers identify strategic options in the changing world. Reviewing the history of world development, we see very obviously that the countries successfully respond to changes gain more chance to grow, while the countries failing to respond the chance have stagnated or declined. China has been changing because of internal system reform and external forces (international trade and FDI). The changes in China, in turn, impact the international environment, which calls on the rest of the world to respond to in turn. This study helps to understand the changes and their implications.

However, this study is not without limitations. The main concern is that this study employs a trade based approach, and trade data is ex post in nature. That means the analysis is based on the information of the past, and it has limitations in making ex ante predictions, especially in case of competitiveness potential. Some non-trade related variables have a higher predictive value such as productivity, unit cost and foreign direct investment etc. These elements are not included because of data availability and practicability of the research framework. This limitation points to directions of the further study.

\section{References}

Adams, F. G., Gangnes, B. \& Shachmurove, Y. (2006). Why is China so Competitive? Measuring and Explaining China's Competitiveness. World Economy, 29(2), 95-122. http://dx.doi.org/10.1111/j.1467-9701.2006.00773.x

Barrell, R., Choy, A., Holland, D. \& Riley, R. (2005). The Sterling Effective Exchange Rate and Other Measures of UK Competitiveness. National Institute Economic Review, 191(1), 54-63. http://dx.doi.org/10.1177/0027950 105052733 
Boltho, A. (1996). The Assessment: International Competitiveness. Oxford Review of Economic Policy, 12(3), 1-16. http://dx.doi.org/10.1093/oxrep/12.3.1

Buckley, P. J., Pass, C. L. \& Prescott, K. (1988). Measures of International Competitiveness: A Critical Survey. Journal of Marketing Management, 4(2), 175-200. http://dx.doi.org/10.1080/0267257X.1988.9964068

Buckley, P. J., Pass, C. L. \& Prescott, K. (1992). The meaning of competitiveness. Servicing International Markets: Competitive Strategy of Firms. Cambridge, Mass.: Blackwell Publishers.

Caves, R. E. (1981). Intra-industry trade and market structure in the industrial countries.

Chen, K. \& Xu, L. (2000). Ex-Post Competitiveness of China's Export in Agri-Food Products: 1980--1996. Agribusiness, 16(3), 281-294. http://dx.doi.org/10.1002/1520-6297(200022)16:3<281::AID-AGR2>3.0.CO;2-4

Corden, W. M. (1994). Economic Policy. Exchange Rate and International System. Oxford University press.

Coldwell, D. III. (2000). The Question of International Competitiveness. International Advances in Economic Research, 6(3), 417-426. http://dx.doi.org/10.1007/BF02294961

DeCourcy, J. (2007). Research Joint Ventures and International Competitiveness: Evidence from the National Cooperative Research Act. Preview Economics of Innovation and New Technology, 16(1-2), 51-65.

El-Namaki, M. S. S. (2002).An Analysis of China's Competitiveness between 1995 and 1999. Competitiveness Review, 12(1), 66-65.

Fagerberg, J. (1988). International competitiveness. The Economic Journal, 98(391), 355-374. http://dx.doi.org/ $10.2307 / 2233372$

Fagerberg, J. (1996). Technology and Competitiveness. Oxford Review of Economic Policy, 12(3), 39-51. http:// dx.doi.org/10.1002/smj.4250100505

Franko, L. G. (1989). Global Corporate Competition: Who's Winning, Who's Losing, And The R\&D Factor As One Reason Why. Strategic Management Journal, 10(5), 449-474. http://dx.doi.org/10.1093/oxrep/12.3.39

Guan, J. \& Ma, N. (2003). Innovative capability and export performance of Chinese firms. Technovation, 23(9), 737-747. http://dx.doi.org/10.1016/S0166-4972(02)00013-5

Havrylyshyn, O. \& Kunzel, P. (1997). Intra-Industry Trade of Arab Countries: An Indicator of Potential Competitiveness. International Monetary Fund Working Papers, No. 97/47.

Hinloopen, J. \& Marrewijk, C. (2004). Dynamics of Chinese comparative advantage. Tinbergen Institute Discussion Papers 04-034/2.

Hu, X., Tu, W. \& Fang, X. (2004). An Analysis and Comparison of Wheat Production Competitiveness between China and the USA. Journal of Economic Issues, 38(4), 1074-82.

Kaminski, B. (2000). Industrial Restructuring as Revealed in Hungary's Pattern of Integration into European Union Markets. Europe-Asia Studies, 52(3), 457-487. http://dx.doi.org/10.1080/713663060

Kojima, K. (2000). The Flying Geese Model of Asian Economic Development: Origin, Theoretical Extensions, and Regional Policy Implication. Journal of Asian Economics, 11(4), 375-401. http://dx.doi.org/10.1016/S1049 $-0078(00) 00067-1$

Kovac ${ }^{\sim} i^{\sim}$ (2007). Benchmarking the Slovenian competitiveness by system of indicators. Benchmarking: An International Journal, 14(5), 553-574.

Krugman, P. (1979). Increasing returns, monopolistic competition and international trade. Journal of International Economics, 9, 469-79. http://dx.doi.org/10.1016/0022-1996(79)90017-5

Krugman, P. B. (1994). Competitiveness: A dangerous obsession. Foreign Affairs, 73(2), 28-44. http://dx.doi.org $/ 10.2307 / 20045917$

Laursen, K. (1998). Revealed comparative advantage and the alternatives as measures of international specialization. DRUID Working Paper, No. 98-30.

MacCharles, D. C. (1987). Trade among multinationals: intra-industry trade and national competitiveness / London: Croom Helm, London.

Makhija, M. V., Kwangsoo, K. \& Williamson, S. D. (1997) Measuring Globalization of Industries Using A National Industry Approach: Empirical Evidence Across Five Countries And Over Time. Journal of International Business Studies, 28(4), 679-710. http://dx.doi.org/10.1057/palgrave.jibs.8490115 
Markusen, J. R. (1992). Productivity, Competitiveness, Trade Performance, and Real Income. Ottawa, Canada: Canada Communication Group.

Marsh, I. W. \& Tokarick, S. P. (1996). An Assessment of Three Measures of Competitiveness. Weltwirtschaftliches Archiv, 132 (4), 700-722. http://dx.doi.org/10.1007/BF02707590

Mendeng, O. J. (1991). International competitiveness and specialization. CEPAL Review, 45, 39-52.

Momoya, K. (1998). Evaluating International Competitiveness at the Industry Level. Vikalpa, 23(2), 39-46.

Oral, M. B (1993). A methodology for competitiveness analysis and strategy formulation in glass industry. European Journal of Operational Research, 68, 9-22. http://dx.doi.org/10.1016/0377-2217(93)90074-W

Ozawa, T. (2005). Institutions, Industrial Upgrading, and Economic Performance in Japan - The 'Flying-Geese Paradigm of Catch-up Growth. Northampton, Massachusetts: Edward Elgar Publishing.

Rugman, A. M. \& Cruz, J. D. (1989). Fast Forward: Improving Canada's International Competitiveness. Toronto: Faculty of Management, University of Toronto.

Sha, K., Yang, J. \& Song, R. (2008). Competitiveness assessment system for China's construction industry. Building Research \& Information, 36(1), 97-109. http://dx.doi.org/10.1080/09613210701561677

Siggel, E. (2001). India's Trade Policy Reforms and Industry Competitiveness in the 1980s World Economy, 24 (2), 159-83. http://dx.doi.org/10.1111/1467-9701.00350

Siggel, E. (2006). International Competitiveness and Comparative Advantage: A Survey and a Proposal for Measurement Journal of Industry. Competition and Trade, 6(2), 137-59. http://dx.doi.org/10.1007/s10842-006-8 430-x

Tyson, L. (1992). Who's Bashing Whom? Trade Conflict in High-Technology Industries. Washington, DC: Institute for International, Economics.

Vernon, R. (1966). International investment and international trade in the product cycle. Quarterly Journal of Economics, 80, 190-207. http://dx.doi.org/10.2307/1880689

Vollrath, T. L. (1991). A theoretical evaluation of alternative trade intensity measures of revealed comparative advantage. Review of World Economics, 127(2), 265-280.

Waitt, G. (1994). Global Competition and the Nature of Trade in the European Community's Pulp and Paper Industry. Economic Geography, 70(1), 60-71. http://dx.doi.org/10.2307/143578

Zhao, Z. \& Zhang, K. H. (2007). China's Industrial Competitiveness in the World. Chinese Economy, 40(6), 6-23. http://dx.doi.org/10.2753/CES1097-1475400601

\section{Notes}

Note 1. See: http://www.weforum.org, the Global Competitiveness Index.

Note 2. For example, in terms of the unit used in trade quantity, China has 4892 6-digit products, among which only 14 products do not match the world statistics. In other countries, such as EU, the mismatch cases is high as 439.

Note 3. In statistics, countries may use different unit for the same commodity. In case the unit of the countries export did not match the unit of the world trade, that particular product group was left out of the calculation. 
Table 1. Relevant Indicators of Competitiveness

\begin{tabular}{|c|c|c|c|c|}
\hline \multirow[t]{2}{*}{ Area } & \multirow[t]{2}{*}{ Indicators (example) } & \multirow[t]{2}{*}{ level } & \multicolumn{2}{|l|}{ Attributes } \\
\hline & & & $\begin{array}{l}\text { Causal vs. } \\
\text { resultant }\end{array}$ & $\begin{array}{l}\text { Current } \\
\text { potential }\end{array}$ \\
\hline $\begin{array}{l}\text { Trade } \\
\text { related }\end{array}$ & $\begin{array}{l}\text { RAC (e.g. Balassa, 1965) } \\
\text { Exports share (e.g. Mandeng 1991) } \\
\text { Trade balance (e.g. Buckley 1988) } \\
\text { Export growth rate (Franko 1989) } \\
\text { Share of manufactured goods } \\
\text { Terms of trade (Daniel III 2000) } \\
\text { Intra-industry trade (Makhija et al. 1997) }\end{array}$ & $\begin{array}{l}\text { Country/industry } \\
\text { Country/industry } \\
\text { Country/industry } \\
\text { Country/industry } \\
\text { Country } \\
\text { Country/industry } \\
\text { Country/industry }\end{array}$ & $\begin{array}{l}\text { Result } \\
\text { Result } \\
\text { Result } \\
\text { Result } \\
\text { cause } \\
\text { cause } \\
\text { cause }\end{array}$ & $\begin{array}{l}\text { Current } \\
\text { Current } \\
\text { Current } \\
\text { Current/potential } \\
\text { potential } \\
\text { potential } \\
\text { potential }\end{array}$ \\
\hline $\begin{array}{l}\text { Productivity } \\
\text { related }\end{array}$ & $\begin{array}{l}\text { Labor productivity } \\
\text { Unit labor cost (e.g. Siggel 2001) } \\
\text { Multi-factor productivity }\end{array}$ & $\begin{array}{l}\text { Country/industry/ } \\
\text { firm } \\
\text { Country/industry/ } \\
\text { firm } \\
\text { Country/industry/ } \\
\text { firm }\end{array}$ & $\begin{array}{l}\text { cause } \\
\text { cause } \\
\text { cause }\end{array}$ & $\begin{array}{l}\text { potential } \\
\text { potential } \\
\text { potential }\end{array}$ \\
\hline $\begin{array}{l}\text { Exchange } \\
\text { rate-related }\end{array}$ & $\begin{array}{l}\text { Equilibrium exchange rate (Barrell 2005, } \\
\text { Marsh 1996) }\end{array}$ & Country & cause & potential \\
\hline
\end{tabular}


Table 2. Competitiveness of industries in China and the EU

\begin{tabular}{|c|c|c|c|}
\hline \multicolumn{2}{|c|}{ China } & \multicolumn{2}{|c|}{$\mathbf{E U}$} \\
\hline \multicolumn{4}{|c|}{ Retreats } \\
\hline 2 & Meat and edible meat offal & 10 & Cereals \\
\hline 4 & $\begin{array}{l}\text { Dairy products, eggs, honey, edible animal } \\
\text { product nes }\end{array}$ & & $\begin{array}{l}\text { Oil seed, oleagic fruits, grain, seed, fruit, etc, } \\
\text { nes }\end{array}$ \\
\hline 8 & Edible fruit, nuts, peel of citrus fruit, melons & 14 & $\begin{array}{l}\text { Vegetable plaiting materials, vegetable } \\
\text { products nes }\end{array}$ \\
\hline 10 & Cereals & 17 & Sugars and sugar confectionery \\
\hline 11 & $\begin{array}{l}\text { Milling products, malt, starches, inulin, } \\
\text { wheat gluten }\end{array}$ & 23 & $\begin{array}{l}\text { Residues, wastes of food industry, animal } \\
\text { fodder }\end{array}$ \\
\hline 12 & $\begin{array}{l}\text { Oil seed, oleagic fruits, grain, seed, fruit, } \\
\text { etc, nes }\end{array}$ & & $\begin{array}{l}\text { Salt, sulphur, earth, stone, plaster, lime and } \\
\text { cement }\end{array}$ \\
\hline 13 & $\begin{array}{l}\text { Lac, gums, resins, vegetable saps and } \\
\text { extracts nes }\end{array}$ & & $\begin{array}{l}\text { Inorganic chemicals, precious metal } \\
\text { compound, isotopes }\end{array}$ \\
\hline 15 & $\begin{array}{l}\text { Animal,vegetable fats and oils, cleavage } \\
\text { products, etc }\end{array}$ & 36 & $\begin{array}{l}\text { Explosives, pyrotechnics, matches, } \\
\text { pyrophorics, etc }\end{array}$ \\
\hline 17 & Sugars and sugar confectionery & 42 & $\begin{array}{l}\text { Articles of leather, animal gut, harness, travel } \\
\text { goods }\end{array}$ \\
\hline 21 & Miscellaneous edible preparations & 61 & $\begin{array}{l}\text { Articles of apparel, accessories, knit or } \\
\text { crochet }\end{array}$ \\
\hline 22 & Beverages, spirits and vinegar & 62 & $\begin{array}{l}\text { Articles of apparel, accessories, not knit or } \\
\text { crochet }\end{array}$ \\
\hline 23 & $\begin{array}{l}\text { Residues, wastes of food industry, animal } \\
\text { fodder }\end{array}$ & 63 & $\begin{array}{l}\text { Other made textile articles, sets, worn } \\
\text { clothing etc }\end{array}$ \\
\hline 27 & Mineral fuels, oils, distillation products, etc & 64 & Footwear, gaiters and the like, parts thereof \\
\hline 29 & Organic chemicals & 65 & Headgear and parts thereof \\
\hline 31 & Fertilizers & 66 & $\begin{array}{l}\text { Umbrellas, walking-sticks, seat-sticks, whips, } \\
\text { etc }\end{array}$ \\
\hline 32 & $\begin{array}{l}\text { Tanning, dyeing extracts, tannins, } \\
\text { derivs,pigments etc }\end{array}$ & 67 & $\begin{array}{l}\text { Bird skin, feathers, artificial flowers, human } \\
\text { hair }\end{array}$ \\
\hline 33 & $\begin{array}{l}\text { Essential oils, perfumes, cosmetics, } \\
\text { toileteries }\end{array}$ & 85 & Electrical, electronic equipment \\
\hline 34 & $\begin{array}{l}\text { Soaps, lubricants, waxes, candles, modelling } \\
\text { pastes }\end{array}$ & 91 & Clocks and watches and parts thereof \\
\hline 37 & Photographic or cinematographic goods & 92 & Musical instruments, parts and accessories \\
\hline 38 & Miscellan & 94 & $\begin{array}{l}\text { Furniture, lighting, signs, prefabricated } \\
\text { buildings }\end{array}$ \\
\hline 39 & Plastics and articles thereof & 95 & Toys, games, sports requisites \\
\hline 40 & Rubber and articles thereof & & \\
\hline 45 & Cork and articles of cork & & \\
\hline 47 & $\begin{array}{l}\text { Pulp of wood, fibrous cellulosic material, } \\
\text { waste etc }\end{array}$ & & \\
\hline 48 & $\begin{array}{l}\text { Paper \& paperboard, articles of pulp, paper } \\
\text { and board }\end{array}$ & & \\
\hline 74 & Copper and articles thereof & & \\
\hline 75 & Nickel and articles thereof & & \\
\hline 79 & Zinc and articles thereof & & \\
\hline 80 & Tin and articles thereof & & \\
\hline 88 & Aircraft, spacecraft, and parts thereof & & \\
\hline
\end{tabular}

88 Aircraft, spacecraft, and parts thereof

\begin{tabular}{ll|ll}
\hline & \multicolumn{3}{c}{ New waves } \\
\hline 1 & Live animals & 1 & Live animals \\
& Live trees, plants, bulbs, roots, cut flowers & & \\
6 & etc & 2 & Meat and edible meat offal \\
18 & Cocoa and cocoa preparations & 3 & Fish, crustaceans, molluscs, aquatic \\
\hline
\end{tabular}




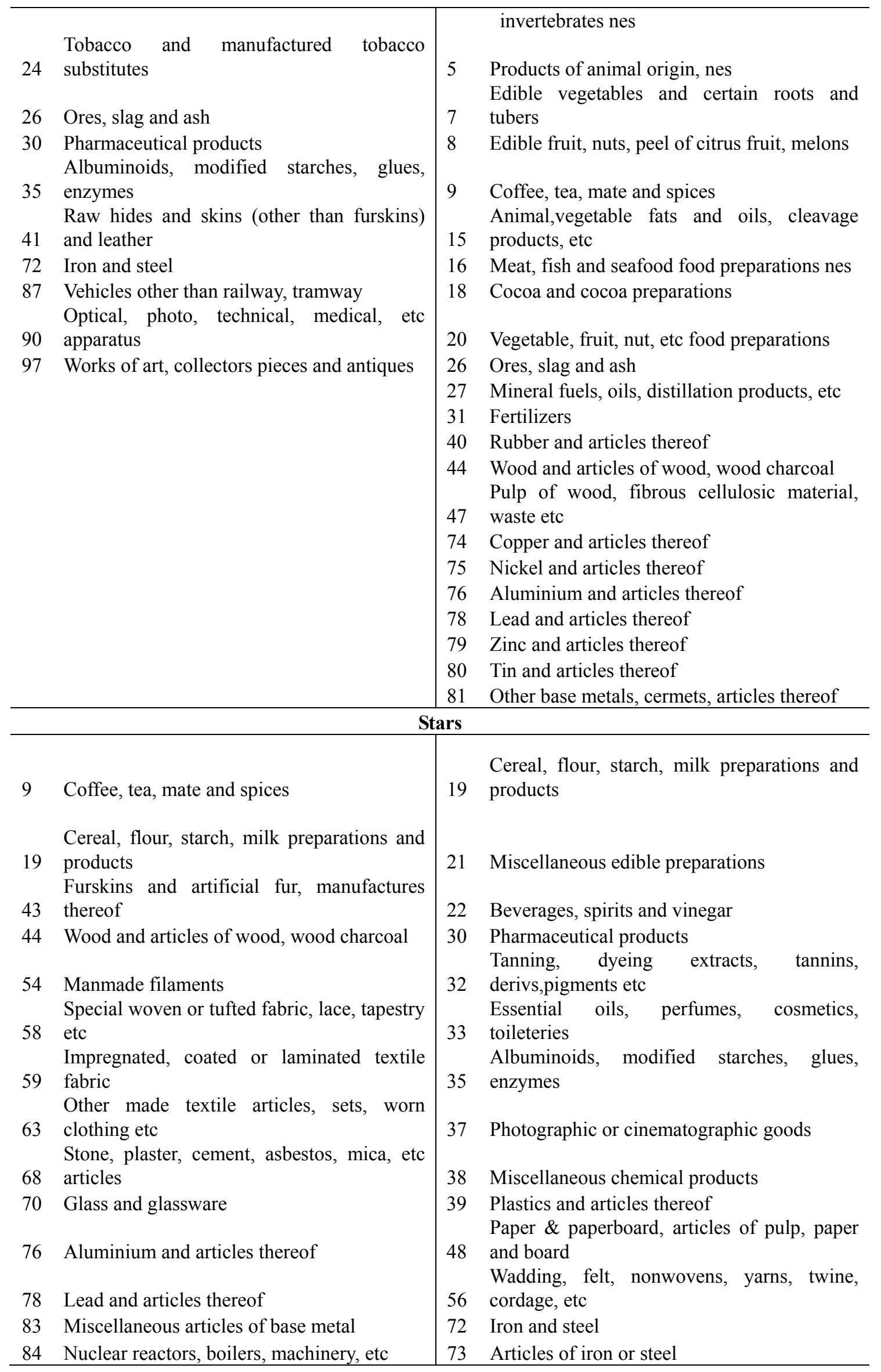


85 Electrical, electronic equipment Railway, tramway locomotives, rolling

86 stock, equipment

89 Ships, boats and other floating structures Arms and ammunition, parts and accessories 93 thereof
87 Vehicles other than railway, tramway

88 Aircraft, spacecraft, and parts thereof Optical, photo, technical, medical, etc 90 apparatus

Arms and ammunition, parts and accessories 93 thereof

\begin{tabular}{|c|c|c|c|}
\hline \multicolumn{4}{|c|}{ Falling stars } \\
\hline 3 & $\begin{array}{l}\text { Fish, crustaceans, molluscs, aquatic } \\
\text { invertebrates nes }\end{array}$ & 4 & $\begin{array}{l}\text { oducts, eggs, honey, edible animal } \\
\text { les }\end{array}$ \\
\hline 5 & Products of animal origin, nes & 6 & $\begin{array}{l}\text { Live trees, plants, bulbs, roots, cut flowers } \\
\text { etc }\end{array}$ \\
\hline 7 & $\begin{array}{l}\text { Edible vegetables and certain roots and } \\
\text { tubers }\end{array}$ & 11 & $\begin{array}{l}\text { Milling products, malt, starches, inulin, } \\
\text { wheat gluten }\end{array}$ \\
\hline 14 & $\begin{array}{l}\text { Vegetable plaiting materials, vegetable } \\
\text { products nes }\end{array}$ & & $\begin{array}{l}\text { Lac, gums, resins, vegetable saps and } \\
\text { extracts nes }\end{array}$ \\
\hline 16 & $\begin{array}{l}\text { Meat, fish and seafood food preparations } \\
\text { nes }\end{array}$ & 24 & $\begin{array}{l}\text { Tobacco and manufactured tobacco } \\
\text { substitutes }\end{array}$ \\
\hline 20 & Vegetable, fruit, nut, etc food preparations & 29 & chemicals \\
\hline 25 & $\begin{array}{l}\text { Salt, sulphur, earth, stone, plaster, lime and } \\
\text { cement }\end{array}$ & 34 & $\begin{array}{l}\text { Soaps, lubricants, waxes, candles, modelling } \\
\text { pastes }\end{array}$ \\
\hline 28 & $\begin{array}{l}\text { Inorganic chemicals, precious metal } \\
\text { compound, isotopes }\end{array}$ & 41 & $\begin{array}{l}\text { Raw hides and skins (other than furskins) and } \\
\text { leather }\end{array}$ \\
\hline 36 & $\begin{array}{l}\text { Explosives, pyrotechnics, matches, } \\
\text { pyrophorics, etc }\end{array}$ & 43 & $\begin{array}{l}\text { Furskins and artificial fur, manufactures } \\
\text { thereof }\end{array}$ \\
\hline 42 & leather, animal gut, harness, & 45 & \\
\hline 49 & , newspapers, pictures etc & 49 & apers, pictures etc \\
\hline 50 & & 50 & \\
\hline 51 & mal hair, horsehair yarn and fabric & 51 & Imal hair, horsehair yarn and fabric \\
\hline 52 & $\mathrm{Cc}$ & 52 & $\mathrm{Co}$ \\
\hline 53 & $\begin{array}{l}\text { le textile fibres nes, paper yarn, } \\
\text { fabric }\end{array}$ & 53 & $\begin{array}{l}\text { ble textile fibres nes, paper yarn, } \\
\text { fabric }\end{array}$ \\
\hline 55 & 15ibm & 54 & filaments \\
\hline 56 & elt, nonwovens, yarns, twine, & 55 & $\mathrm{M}$ \\
\hline 57 & other textile floor coverings & 57 & spestry \\
\hline 60 & $\mathrm{~K}$ & 58 & \\
\hline 61 & of apparel, accessories, knit or & 59 & $\begin{array}{l}\text { Impregnated, coated or laminated textile } \\
\text { fabric }\end{array}$ \\
\hline 62 & of apparel, accessories, not knit or & 60 & $\mathrm{~K}$ \\
\hline 64 & Foo & 68 & plaster, cement, asbestos, mica, etc \\
\hline 65 & $\mathrm{He}$ & 69 & Ceramic products \\
\hline 66 & $\begin{array}{l}\text { as, walking-sticks, seat-sticks, } \\
\text { tc } \\
\text { n, feathers, artificial flowers, human }\end{array}$ & 70 & re \\
\hline 67 & & 71 & ins \\
\hline 69 & & 82 & base metal \\
\hline 71 & tc & 83 & M \\
\hline 73 & eel & 84 & chinery, etc \\
\hline
\end{tabular}


81 Other base metals, cermets, articles thereof

82 Tools, implements, cutlery, etc of base metal

91 Clocks and watches and parts thereof

92 Musical instruments, parts and accessories Furniture, lighting, signs, prefabricated

94 buildings

95 Toys, games, sports requisites

96 Miscellaneous manufactured articles
Railway, tramway locomotives, rolling stock,

86 equipment

89 Ships, boats and other floating structures

96 Miscellaneous manufactured articles

97 Works of art, collectors pieces and antiques

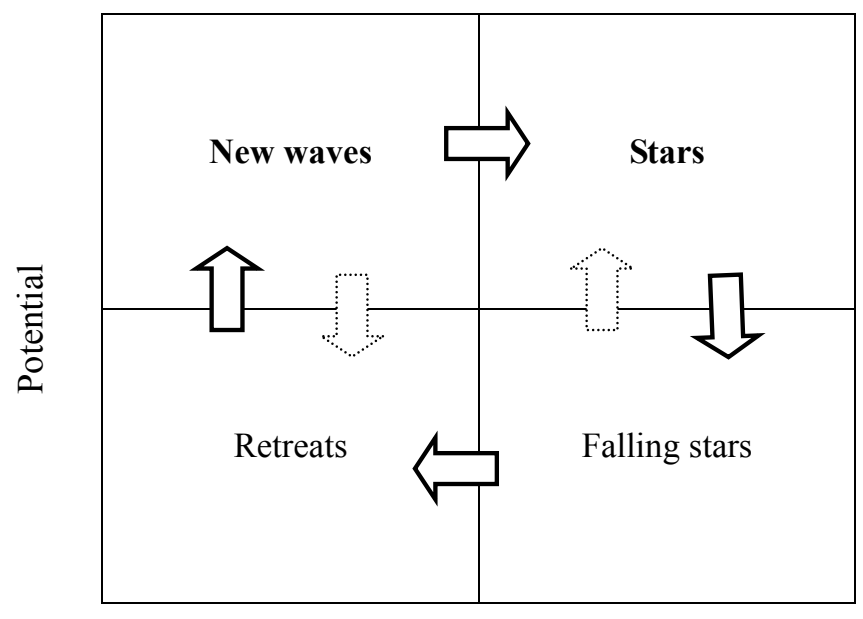

Performance

Figure 1. Competitiveness matrix

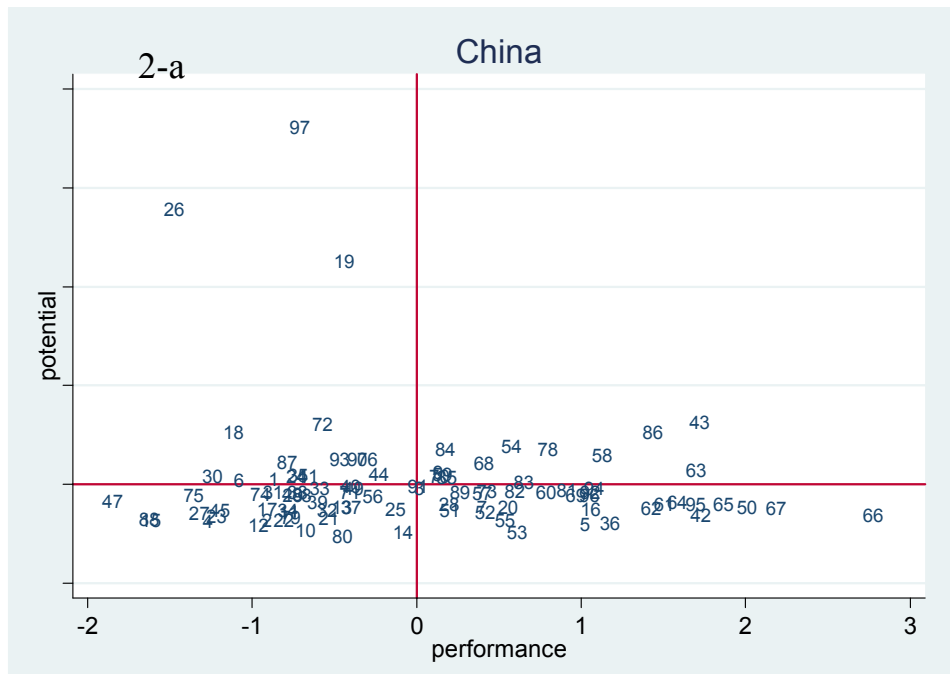




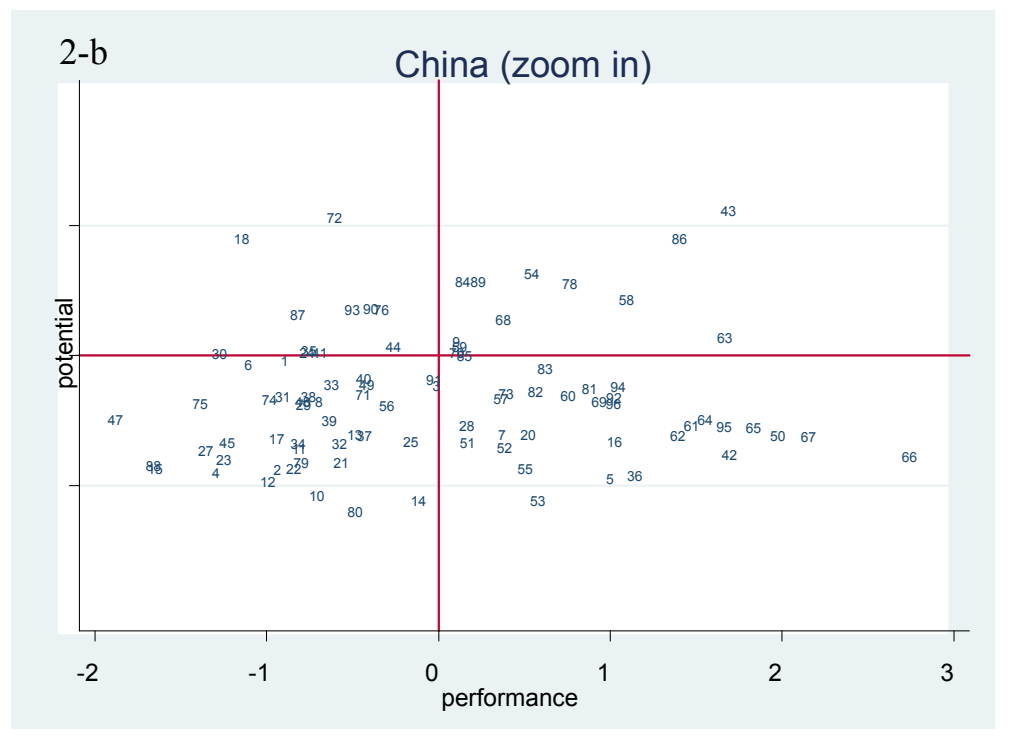

Figure 2. Competitiveness of Chinese industries

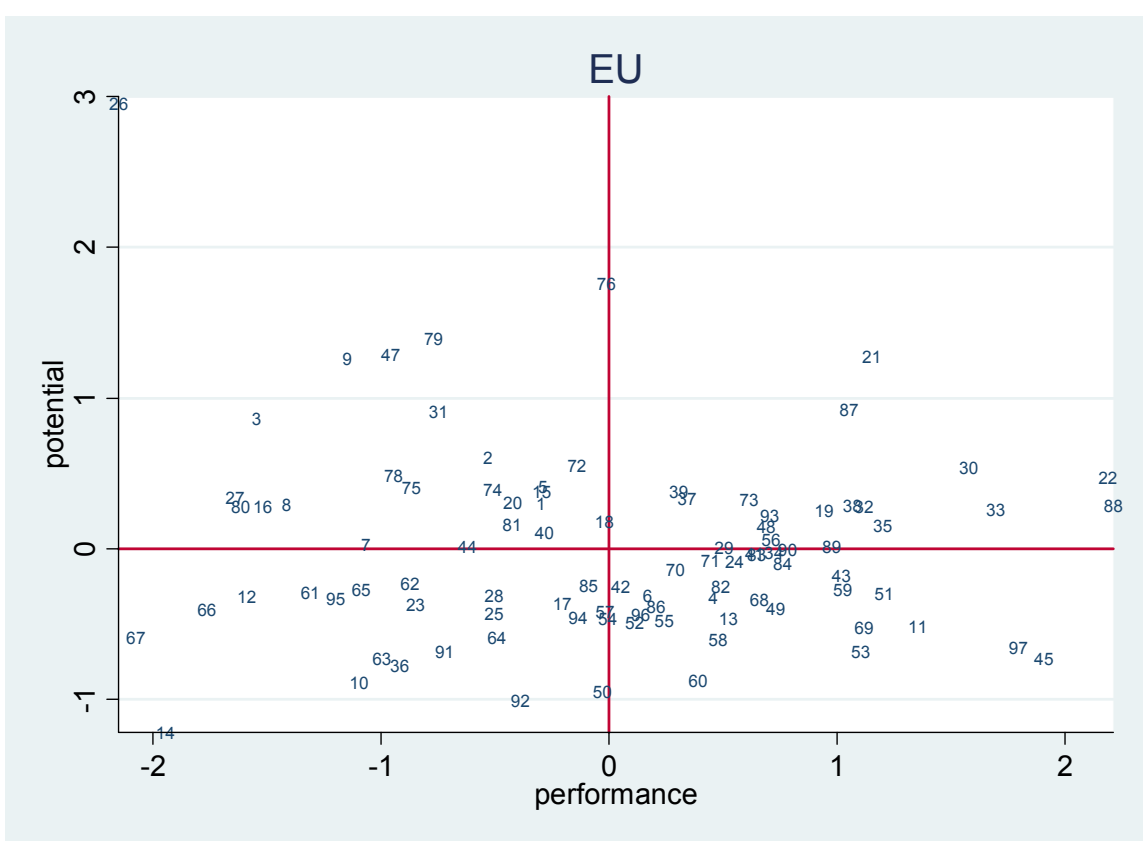

Figure 3. Competitiveness of the EU industries 


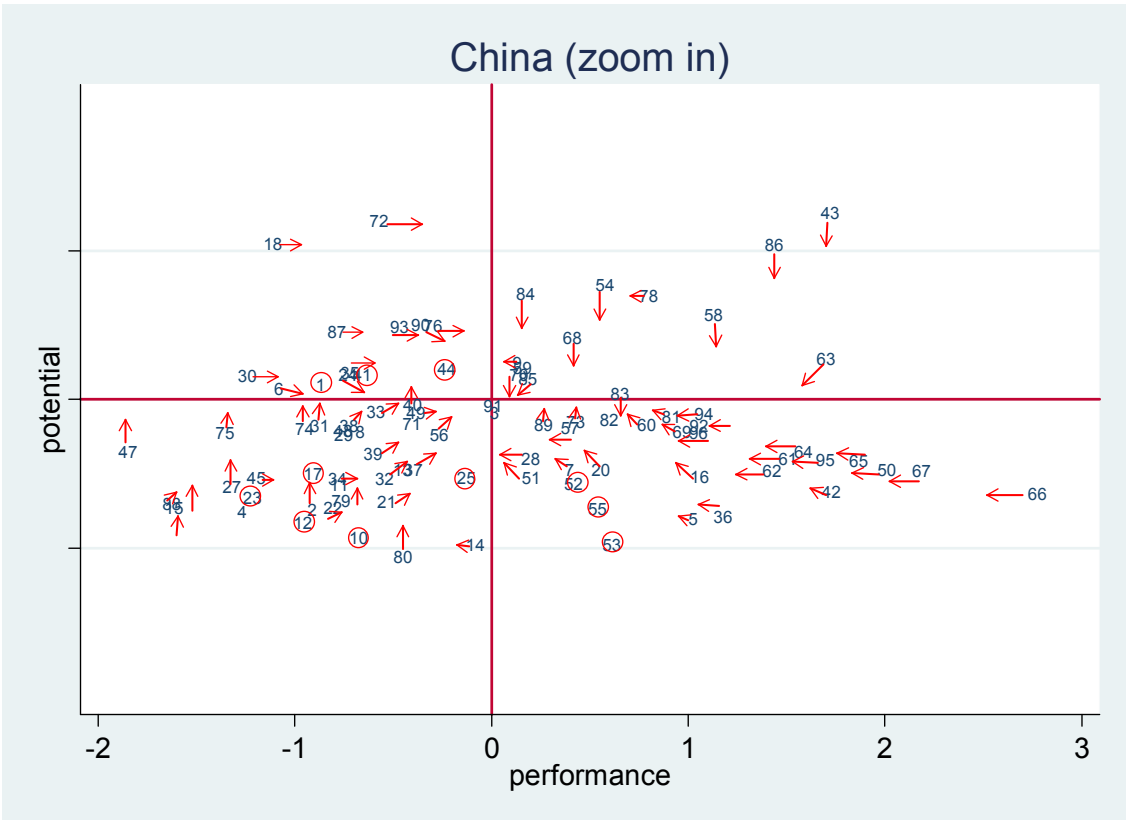

Figure 4. Competitiveness of Chinese industries related to the EU industries

Note: arrows indicate the location of the EU industries in the Figure. 3 